University for Business and Technology in Kosovo

UBT Knowledge Center

UBT International Conference

2017 UBT International Conference

Oct 28th, 9:00 AM - 10:30 AM

\title{
The Actual Paradigm of Freedom of Movement in the Context of EU Migrants Rights
}

\author{
Elitsa Kumanova \\ University of Ruse \\ Zornitsa Yordanova \\ University of Ruse \\ Elina Marinova \\ University of Ruse \\ Doroteya Dimova-Severinova \\ University of Ruse \\ Ivelin Velchev \\ University of Ruse
}

Follow this and additional works at: https://knowledgecenter.ubt-uni.net/conference

Part of the Law Commons

\section{Recommended Citation}

Kumanova, Elitsa; Yordanova, Zornitsa; Marinova, Elina; Dimova-Severinova, Doroteya; and Velchev, Ivelin, "The Actual Paradigm of Freedom of Movement in the Context of EU Migrants Rights" (2017). UBT International Conference. 218.

https://knowledgecenter.ubt-uni.net/conference/2017/all-events/218

This Event is brought to you for free and open access by the Publication and Journals at UBT Knowledge Center. It has been accepted for inclusion in UBT International Conference by an authorized administrator of UBT Knowledge Center. For more information, please contact knowledge.center@ubt-uni.net. 


\title{
THE ACTUAL PARADIGM OF FREEDOM OF MOVEMENT IN THE CONTEXT OF EU MIGRANTS RIGHTS
}

\author{
Elina Marinova ${ }^{1}$, Elitsa Kumanova ${ }^{2}$, Zornitsa Yordanova ${ }^{3}$ \\ Doroteya Dimova ${ }^{4}$, Ivelin Velchev ${ }^{5}$ \\ 1,2,3,4,5 University of Ruse “Angel Kancev”, Law Faculty, Public Law Department \\ $\left\{\right.$ elina_marinova ${ }^{1}$, ekumanova $^{2}$, ziordanova $^{3}$, \\ ddimova $^{4}$, ivelchev $\left.{ }^{5}\right\} @$ uni-ruse.bg
}

\begin{abstract}
The purpose of this paper is examination of the current dimensions of the freedom of movement of persons in the EU, which is a milestone in the construction of the European space. The refugee wave in the last decade, following the onset of the "Arab spring", has raised new questions about the rights and status of persons, who had left their countries because of military conflicts or civil wars and sought asylum in EU countries. Bulgaria has been unprepared to respond adequately to the protection of the EU's external border from illegal immigration and has rethought key issues such as securing national sovereignty, legal respect for refugee rights and financial provision of resource support for them by state institutions
\end{abstract}

Keywords: freedom of movement, migrants rights, public funding

\section{Introduction}

Six decades after the European unification process began, the idea of the compatibility of individual freedom with the freedom of others continues to develop. Robert Schumann says that "peace cannot be safeguarded without an effective effort proportionate to the threats to it."67 One of the most important guarantees for the freedom of society is to ensure the fundamental rights and freedoms of the citizens of the European Union. "Freedom and human rights are universal and indivisible. They do not depend on the differences in nationality of the individual countries, or on the belonging to a separate ethnic or social group." ${ }^{68}$ Human rights and freedoms stem from the stability of the human personality, from human dignity and human social essence. Human rights are inseparable from human nature and are connected with its very existence. The notion of human rights expresses the universal value of man, which manifests itself in the personality of the individual. The distribution of goods and legal positions is done by measuring them ${ }^{69}$ in accordance with social justice in order

${ }^{67}$ Chalmers D., C. Hadjiemmanuil, G. Monti, A. Tomkin. European Union Law. Cambridge University press, 2006, p. 9

${ }^{68}$ Program of the Liberal International. Quote "Liberalism and Free Speech", series "Liberal Library", 1998, no. No 9

${ }^{69}$ Dachev, L. Juridical discourse, Ruse, Svida press, 2004, p.174-238 
to achieve a fair balance between "the granted" and "the obtained". Thus, the law provides legal entities with opportunities for self-determination and expression of free will and becomes a measure of social freedom. ${ }^{70}$

\section{The right of free movement}

The right of free movement of people is a natural weal that has been institutionalized through the state constitutions and a number of international instruments. Freedom is the highest spiritual value. It allows legal entities to act independently, independently and without compulsion, in expressing their own will, without violating established regulatory imperatives. The freedom of movement is an expression of self-determination of the will. It is expressed as a subjective right, as a legal authority over a weal. By exercising this subjective right, the legal persons have a legal opportunity to reorganize their existence by moving from one place to another in accordance with their individual needs and visions for a better life. The freedom of movement is an individual, natural, equitable and private weal. The "private" and "individual" good should not be mixed or considered to be in accordance with its characteristics. Its individual nature results from its being granted for the exercise of legal entities. The private nature is in view of its orientation to the personal interest and purpose of the person who exercises it. These two features are key to defining the escalating problem of the "boundaries" of the freedom and non-freedom of the subjects, their protection and their responsibility in realizing the right of free movement.

The armed conflicts and the refugee crisis over the last few years pose significant issues deserving of a major research, including challenges to security and sovereignty in providing different forms of protection, providing the necessary financial resources to fulfill the defense and social function of the state vis-à-vis vulnerable categories of foreigners. State sovereignty, understood as the independence of state and state power from other states and government, represents the possibility that the state can independently exercise its power, its external and internal policies. In this way the state will guarantee its territorial integrity and national security. The issue that arises before the state-organized society has been a conflict between human rights, the right to freedom of movement and national security and domestic order, respectively the possibility for the state to exercise its rule of authority. The topic leads to a multi-layered philosophical and ethical, legal and political theme for a reasonable balance between freedom and security as the defensive values of a democratic society and the rule of law. The European Chart of Human Rights (ECHR) establishes minimum set of standards for the protection of human rights and fundamental freedoms. In some cases, however, state power is needed to undermine violations of the right to liberty. The European legislator allows the restriction of the right to liberty where this is conditioned by the protection of the state and public interest.

The ECHR precisely and comprehensively regulates the cases in which the limitation is possible (Article $5 \S 1$ (b) "a" - "f"). The historical development of state organized societies depicts situations of distortion and limitation of the interests of certain individuals or groups in society. In order to eliminate this, it is necessary for state policies to be justified by the existing value system in society.

${ }^{70}$ Mihailova M. Theory of Law. S., Feney, 2002, p.47-48 
Regarding refugees, it is necessary to take specific measures for inclusion and socialization. ${ }^{71}$ Their integration into public life will also prevent the possibility of encapsulation in separate, almost nonstate, groups.

In 1999, the European Council endorsed the need for a common European asylum and migration policy by adopting a decision to introduce a single European system. In order to establish a sustainable regulatory and institutional basis for successful migration management and related processes, Bulgaria, as a member state of the European Union, has adopted a National strategy on migration, asylum and integration 2015-2020.

\section{The Regulation in Bulgaria}

The Constitution of the Republic of Bulgaria also provides the right of asylum in Article 27 (2). The detailed regulation of this right, as well as the status of refugees and other special legal regimes applicable to threatened categories of aliens, is contained in the Asylum and Refugees Act (ARA). The protection that Bulgarian legislation can provide to foreigners within the meaning of the ARA includes asylum, international protection and temporary protection. The asylum is a constitutional category and is issued with a Presidential decree for foreigners persecuted for their beliefs or activity in defense of internationally recognized rights and freedoms (under the ARA - "as well as when state interests or special circumstances impose this"). International protection is provided by an act of the Chairman of the State Agency for Refugees under the Geneva Convention on the Status of Refugees of 28 July 1951 and other international human rights instruments. This act includes refugee status and humanitarian status ${ }^{72}$. The third form of protection - the so-called temporary protection is granted by the Council of Ministers (upon a decision of the EU Council and for the period stipulated in the decision) in case of mass influx of foreigners forced to leave their country of origin due to armed conflict, civil war, foreign aggression, violation of human rights or indiscriminate violence on the territory of the relevant country or in a part of the country, and who for these reasons are unable to return there.

Within the European Union (EU), efforts are being made to provide adequate funding for those policy areas where Member States face collective challenges. The refugee crisis is undoubtedly a challenge. The associated increase in public spending is usually due to border security needs

\footnotetext{
${ }^{71} \mathrm{We}$ are witnessing how large social groups in society live in their communities without trying to integrate. They live by their own rules, often in violation of moral, cultural and legislative norms. This is also true in the "most developed democratic and social" countries.

${ }^{72}$ Refugee status in Bulgaria shall be granted to an alien who for reasons of a well-founded fear of persecution due to his/her race, religion, nationality, political opinion or membership of a specific social group is outside his/her country of origin and who, for those reasons, is unable or unwilling to avail himself/herself of the protection of that country or return thereto. Humanitarian status shall be granted to an alien who is not eligible for refugee status and who does not wish or is unable to receive protection from his/her country of origin as he/she may face a real risk of suffering serious harm, such as:death penalty or execution, ortorture or inhuman or degrading treatment or punishment, or serious threat to a civilian's life or person by reason of indiscriminate violence in situations of international or internal armed conflict.
} 
(especially with regard to the EU's external border), registration of asylum seekers and short-term food provision, health care and shelter in transit countries. For countries of destination, public spending is focused on integration, housing provision, language learning, and various social benefits.

An additional fiscal impact for the Member States most affected is expected to be in the range of $0.1-0.6 \%$ of GDP cumulatively. ${ }^{73}$

During the period $2014-2020^{74}$ provision of asylum, migration and integration funding will continue to be mainly under shared management (ie a joint effort between EU countries and the European Commission). Member States are committed to securing adequate national funding. On the other hand, there are a number of programs whereby the EU provides financial resources to both its Member States and non-EU countries ("third countries") to support their efforts in the areas of regulated and legal migration, illegal migration, asylum provision, visa policy, border management and integration. ${ }^{75}$ The main EU financial instruments for support in this area are the Asylum, Migration and Integration Fund (AMIF) and the Internal Security Fund -borders and visas (ISF), which provide $€ 6.8$ billion for the seven-year period of which $€ 4.33$ billion shall be allocated directly to the Member States. ${ }^{76}$ Eligible expenditure categories under AMIF and ISF are those eligible for funding under Regulation (EU) No 514/2014 of the European Parliament and of the Council of 16 April 2014 laying down general provisions for the Asylum, Migration and Integration Fund "And on the Financial Assistance Facility for police cooperation, the prevention and fight against crime and crisis management (OJ L 150, 20.5.2014). The European Commission also provides additional funds for temporary measures to relocate refugees from other countries. The management of EU funds for migration is primarily decentralized. This situation means that Member States have the ultimate responsibility for the financial management of their multiannual and annual programs implemented within these funds. They implement decentralized management and control systems to oversee the implementation of the Funds by delegating the audit work of professional external audit bodies or national audit institutions.

According to the Bulgarian legislation the sources of funding for asylum, migration and integration measures are the state budget, the EU Fund for Asylum, Migration and Integration and other EU complementary funds as well as funds provided by international institutions. Funds for Bulgaria under AMIF amount to EUR 10,006,777 million, to which is added the national co-financing amounting to about EUR 13 million. ${ }^{77}$ The Law on the State Budget of the Republic of Bulgaria for 2017 (promulgated SG 98/9 dated 9 December 2016, in force since January 1, 2017) under the budget program "Asylum and Refugees", area "Provision of the activity and organization of the work of the Council of Ministers envisages BGN 8 million, including maintenance of the State Agency for Refugees at the Council of Ministers. The latter is also a co-beneficiary in the Grant Agreement "Strengthening the National Capacity of the Republic of Bulgaria in the Asylum and

${ }^{73}$ An Economic take on the refugee crisis, European Economy Institutional Papers, JULY 2016, p. 3.

${ }^{74}$ Information on the parameters outlining the new programming period (2014-2020) of the Asylum, Migration and Integration Fund can be found on the European Commission's website, Migration and Home Affairs - https://ec.europa.eu/home-affairs/financing/fundings/migration-asylumborders/asylum-migration-integration-fund

${ }^{75}$ Asylum, Migration and Integration Fund, Internal Security Fund, Horizon 2020, Employment and Social Innovation Program, Rights, Equality and Citizenship Program, etc.

${ }^{76}$ According to Annex I of the AMIF Regulation; Annex I of the ISF-Border Regulation and Annex III of the ISF - Police Regulation.

${ }^{77}$ National Strategy for the Integration of Persons Received International Protection in the Republic of Bulgaria 2014-2020, Chapter XIII - Funding 
Migration Fund under the Asylum, Migration and Integration Fund (Emergency Measures 20162017), providing funding of 9550563 for the period, incl. BGN 501077 for staff, BGN 6585956 for maintenance and BGN 2463539 for capital expenditures. The provision of public services to persons is financed within the budgets of the relevant departments and the provision of additional services is financed through targeted budgets.

\section{Results}

The chaotic influx of refugees and migrants, the lack of personal documents in them, the lack of information about their health status, the non-observance of basic national and human values, the non-recognition of other religious communities, the poor integration, the lack of knowledge of the legislation, the local customs are basic problems related to migration and refugee flows. On the backdrop of frequent acts of terrorism, cases of aggression, crime, riots at mass events, the feeling of fear and helplessness of citizens has been shown to increase. The endangering of community goods strengthens the feeling that the society is endangered, which increases aggression and discrimination. Despite the efforts and restrictions imposed by many of the countries in Europe, problems remain unresolved and public concern is growing. On the other hand, limiting the right to free movement leads to the abolition of individual subjective right and apostasy from seeking to establish a person as a higher value.

The challenge facing Europe and Bulgaria nowadays is enormous - to ensure national sovereignty, to prevent violation of the rights of migrants and refugees, and to secure financially institutions that "welcome" the flows of people looking for a better future. The problem is extremely delicate and complex. It is necessary to prevent or at least severely curb illegal migration, to provide legal and safe ways for persons seeking international protection and to ensure their integration - physical, spiritual, administrative, financial, health, educational. The reasonable measure of the allowed freedom over the goods must be revealed and the limit of permissible non-freedom determined in such a way that neither private nor public subjective rights are put in jeopardy.

\section{References}

1. An Economic take on the refugee crisis, European Economy Institutional Papers, JULY 2016

2. Butorina O., Kaveshnikov N., European integration, Aspect press, 2017

3. Chalmers D., C. Hadjiemmanuil, G. Monti, A. Tomkin. European Union Law, Cambridge University press, 2006

4. Dachev, L., Juridical discourse, Ruse, Svida press, 2004

5. Dachev, L., The state as an organization, Research papers - University of Ruse, 2012, Volume 52, Series 7

6. Fukuyama, F., State-Building, S., Obsidian, 2004

7. Gombos, K., The methods of Judicial Protection in the European Union, Lambert Academic Publishing, 2014

8. Mihailova M., Theory of Law, S., Feney, 2002 
9. Program of the Liberal International. Quote "Liberalism and Free Speech", series "Liberal Library", 1998, no. No 9

10. Philosophical dictionary, Moscow, Political literature press, 1968

11. Law on the State Budget of the Republic of Bulgaria for 2017 (Promulgated in State Gazette No 98 of 9 December 2016, in force since 1 January 2017)

12. National Strategy for the Integration of Persons Received International Protection in the Republic of Bulgaria 2014-2020

13. Nugent, N., The government and politics of the European Union, Palgrave, 2017

14. Regulation No 513/2014 / EU of the European Parliament and of the Council of 16 April 2014 establishing an instrument for financial support for police cooperation, preventing and combating crime and crisis management as part of the Internal Security Fund.

15. Regulation (EU) No 514/2014 of the European Parliament and of the Council of 16 April 2014 laying down the general arrangements for the Fund for Asylum, Migration and Integration and the Instrument for financial support for police cooperation, preventing and combating crime and crisis management.

16. Regulation (EU) No 516/2014 of the European Parliament and of the Council of 16 April 2014 establishing the Asylum, Migration and Integration Fund and amending Council Decision 2008/381 / EC and repealing Decisions No 573 / 2007 / EC and No 575/2007 / EC of the European Parliament and of the Council and of Council Decision 2007/435 / EC.

17. The European Commission's Internet site, Migration and Home Affairs https://ec.europa.eu/home-affairs/financing/fundings/migration-asylum-borders/asylummigration-integration-fund. 